\title{
ОЦІНЮВАННЯ СИСТЕМИ ВНУТРІШНЬОГО КОНТРОЛЮ ПІДПРИЄМСТВА В ПРОЦЕСІ АУДИТУ ФІНАНСОВОЇ ЗВІТНОСТІ: МЕХАНІЗМ, КРИТЕРІЇ, ПРОБЛЕМИ ТА СПОСОБИ ЇХ УСУНЕННЯ
}

\begin{abstract}
Анотація. У статті розглядаеться механізм оцінювання системи внутрішнього контролю підприемства під час аудиту його фінансової звітності, а також аналізуються проблеми, пов'язані з процесом оцінювання. Досліджено методи оцінювання системи внутрішнього контролю, які грунтуються на використанні як кількісних, так і якісних показників. Розглянуто переваги та недоліки методів оцінювання системи внутрішнього контролю, а також наведено критерії, які доцільно застосовувати під час оцінювання. Узагальнено етапи оцінювання системи внутрішнього контролю підприемства під час аудиту фінансової звітності, а також структуровано елементи піеї системи для комплексного оцінювання. Крім того досліджено зовнішні та внутрішні чинники, які впливають на оптимальність організування системи внутрішнього контролю підприемства, а також на ефективність та надійність їі функціонування. Запропоновано способи усунення низки проблем, що існують на сьогодні в процесі оцінювання системи внутрішнього контролю під час аудиторської перевірки фінансової звітності підприемств.
\end{abstract}

Ключові слова: система внутрішнього контролю, критерії оцінювання, елементи внутрішнього контролю, ефективність системи внутрішнього контролю, проблеми оцінювання.

Chubai Volodymyr, Hrytseliak Olha Lviv Polytechnic National University

\section{EVALUATION OF THE INTERNAL CONTROL SYSTEM OF THE ENTERPRISE IN THE FINANCIAL STATEMENT AUDIT PROCESS: MECHANISM, CRITERIA, PROBLEMS AND WAYS TO ELIMINATE THEM}

Summary. The article considers the mechanism of evaluation of enterprise internal control system during the verification of its financial viability, and analyzes the problems associated with the evaluation process. The methods of evaluation of the internal control system, which are based on the use of both quantitative and qualitative indicators, are studied. The advantages and disadvantages of methods of evaluating the internal control system are considered, and the criteria that should be used during the evaluation are given. The stages of evaluation of the enterprise internal control system during the audit of financial statements are summarized, and the elements of this system for comprehensive assessment are structured. In addition, the external and internal factors influencing optimality of the organization of enterprise system of internal control are investigated, as well as the efficiency and reliability of its operation. Ways to eliminate a number of problems that currently exist in the process of evaluating the internal control system during the audit of enterprises financial statements are proposed. The approaches of different scientists to the selection of elements of the enterprise internal control system and the requirements of international auditing standards for the components of internal control are studied. Aspects that need to be considered when evaluating each element of this system during the audit of the enterprise financial statements are also considered. The optimal set of objects that need to be controlled by an internal control system in order to promote the effective balanced development of the enterprise are separated. Directions of using the results of evaluation of the internal control system both during the audit of financial statements by audit firms and during the adoption of current, tactical and strategic management decisions by management of enterprise are systematized. The parameters with which it is possible to estimate the system of internal control (SIC) of the enterprise are detailed in the context of such criteria as: the level of human resources involved in the SIC; the level of information, technical-technological and financial support of the SIC; state of the environment functioning of SIC; the level of quality of internal control measures within the SIC.

Keywords: internal control system, evaluation criteria, elements of internal control, efficiency of the internal control system, evaluation problems.

$\Pi^{2}$ остановка проблеми. Для визначення рівня аудиторського ризику, притаманного аудиту фрінансової звітності конкретного підприемства, і для визначення необхідної кількості аудиторських процедур з метою виявлення різних типів викривлень у ній, аудитору необхідно мати відповідний рівень розуміння системи внутрішньогосподарського контролю цього підприемства. Доцільність їі оцінювання грунтуеться на припущенні, що ефрективна система внутрішнього контролю здатна забезпечити відсутність відхилень (помилок, порушень, шахрайства тощо), що стали наслідком навмисних та ненавмисних дій. При високій ефек- тивності цієї системи, рівень ризику контролю буде мінімальним, i, як наслідок, аудитор може зменшити кількість і масштаб аудиторських процедур, спрямованих на виявлення відхилень у фрінансовій звітності. На сьогодні суб'єкти аудиторської діяльності гостро потребують обгрунтованих методик оцінювання системи внутрішнього контролю підприемства, однак результати відповідних наукових досліджень в сучасній економічній літературі є досить дискусійними.

Аналіз останніх досліджень та публікацій. Питаннями оцінювання системи внутрішнього контролю підприемства присвячені праці 
зокрема таких вітчизняних та зарубіжних вчених: Пена Л. В., Долбуля О. О. [1], Патраманська Л. Ю. [2], Кароль В. В. [3], Максімова В. Ф., Ковальова Н. М. [4], Дорош Н. І. [5], Свтушевська О. А. [6], Чубай В. М. [7], Будник Л. А., Голяш І. Д. [8], Рядська В. В. [9], Болдуєв М. В. [10] Аренс Е., Лоббек Дж. [11], Ф. Л. Дедрліз, Г. Р. Дженік [12] та інші. Однак й досі більшість недоліків організації і методики оцінювання цієї системи поки ще не усунуто.

Щоб всебічно дослідити та ощінити систему внутрішнього контролю підприемства, насамперед, необхідно розглянути сутність цього поняття. Підходи вчених до визначення поняття «система внутрішнього контролю» відрізняються між собою, а інколи навіть суперечать один одному. Одне 3 найвлучніших трактувань цього поняття наводить Петрик О. А., яка вважає, що внутрішній контроль - це незалежна діяльність на підприемстві з перевірки й оцінювання його роботи 3 позиції його ж інтересів, тобто це діяльність 3 надання незалежних та об'єктивних гарантій i консультацій, спрямованих на удосконалення господарської діяльності підприемства [13].

Щоб всебічно оцінити систему внутрішнього контролю підприемства необхідно виокремити елементи ціеї системи. В міжнародному стандарті аудиту (MCA) 315 виділено такі компоненти внутрішнього контролю: середовище контролю; процес оцінки ризиків суб'єкта господарювання; інформаційна система, включаючи пов'язані бізнес-процеси, доречні для фрінансової звітності, та повідомлення інформації; заходи контролю доречні для аудиту; моніторинг заходів контролю [14]. Однак аналізуючи цей поділ, на нашу думку в МСА не враховано системний підхід, що спричинить труднощі достовірного ощінювання едективності внутрішнього контролю на підпри- ємстві. У науковій літературі відсутній єдиний підхід до виділення елементів системи внутрішнього контролю підприемства. Зокрема Е. Аренс та Дж. Лоббек виділяють три елементи: середовище контролю; облікова система; процедури контролю [11]. Окремі автори звужують елементи системи внутрішнього контролю виключно до середовища контролю та заходів контролю [15]. В. В. Рядська [9] притримується поділу на елементи, який наведений в МСА 315. Дослідження літературних джерел показуе, що такі елементи, як середовище контролю і заходи контролю (процедури контролю) виділяють всі автори.

Вибираючи підхід до ощінювання системи внутрішнього контролю підприемства необхідно пам' ятати як про їх переваги, так і недоліки (рис. 1).

Враховуючи недоліки як якісної, так і кількісної оцінки ефективності контролю, слід впроваджувати інтегральний підхід, який би синтезував в собі декілька підходів, що дасть змогу сформувати комплексне бачення ефрективності внутрішнього контролю.

Процедура оцінювання едективності системи внутрішнього контролю є обов'язковою для всіх підприемств-замовників аудиту фрінансової звітності. Вона здійснюеться як на етапі планування, так і на етапі безпосередньої аудиторської перевірки даних обліку і звітності. Маючи у своєму розпорядженні матеріали дослідження, виконаного перед укладанням договору на етапі планування, звіт попереднього аудитора, інші матеріали, аудитор отримує загальне уявлення про специфіку і масштаби діяльності підприемства, систему бухгалтерського обліку, структуру системи внутрішнього контролю та їі місце в системі управління, оцінюе рівень едективності системи внутрішнього контролю у періоді, що перевіряеться, і на момент перевірки. На рис. 2 на-

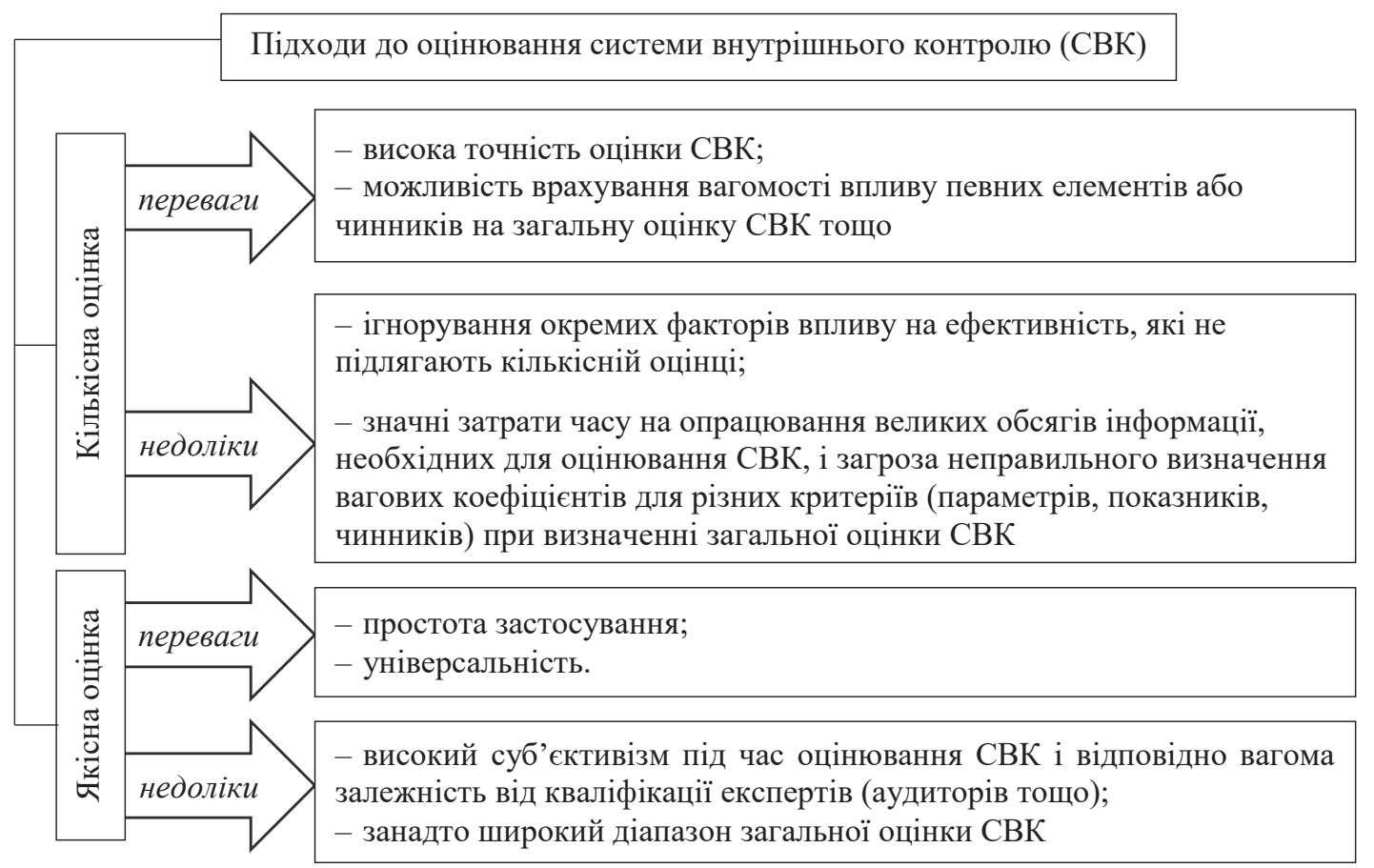

Рис. 1. Переваги та недоліки підходів до оцінювання системи внутрішнього контролю підприемства 
Методичні прийоми дослідження системи внутрішнього контролю (СВК) підприємства

\begin{tabular}{|c|c|}
\hline $\begin{array}{c}\text { Дослідження СВК на предмет наявності } \\
\text { конфлікту інтересів у суб’єктів } \\
\text { контролю, її незалежності тощо }\end{array}$ & $\begin{array}{c}\text { Опитування персоналу підрозділів } \\
\text { підприємства щодо механізму та } \\
\text { особливостей здійснення } \\
\text { внутрішнього контролю }\end{array}$ \\
\hline Запит до попереднього аудитора & Oонц \\
\hline $\begin{array}{l}\text { Повторна перевірка певних первинних } \\
\text { документів та регістрів обліку, активів і }\end{array}$ & $\begin{array}{c}\text { автоматизації різних засобів та } \\
\text { процедур контролю }\end{array}$ \\
\hline $\begin{array}{c}\text { зобов’язань, господарських операцій } \\
\text { тощо, які перед тим були перевірені } \\
\text { СВК }\end{array}$ & $\begin{array}{c}\text { Аналіз підсумкових документів } \\
\text { попередніх аудиторських та інших }\end{array}$ \\
\hline $\begin{array}{l}\text { Тестування системи внутрішнього } \\
\text { контролю в розрізі різних об’єктів }\end{array}$ & перевірок в частині оцінки СВК \\
\hline
\end{tabular}

Рис. 2. Методичні прийоми дослідження системи внутрішнього контролю підприемства під час аудиту фінансової звітності

Джерело: узагальнено на основі [16; 17; 18; 19]

ведено методичні прийоми дослідження системи внутрішнього контролю підприємства.

Різноманітність результатів внутрішнього контролю та його напрямів здійснення зумовлюе складність визначення єдиного критерію для ощннювання едрективності. Ця ситуація зумовила й той фракт, що на даний час навіть на теоретичному рівні все ще не запропонована едина методика для ощнювання едрективності системи внутрішнього контролю під час аудиту фрінансової звітності. Основна причина такої ситуації - відсутність єдиної позиції щодо елементів цієї системи, критеріїв і показників її оцінювання. Проблематичним $є$ й оцінювання едективності системи внутрішнього контролю на основі одного комплексного показника, наскільки б складним він не був, адже ефективність ціеї системи занадто багатогранна категорія.

Серед окремих кількісних показників оцінювання системи внутрішнього контролю в науковій літературі можна виділити, зокрема, такі: коефіцієнт співвідношення вартості резервів, виявлених протягом звітного періоду, до витрат звітного періоду на створення/удосконалення та фрункціонування системи внутрішнього контролю або витрат на організацію та проведення окремого контрольного заходу; коефіцієнт співвідношення відшкодованої шкоди, завданої підприємству протягом звітного періоду, до витрат звітного періоду на створення/удосконалення та фрункціонування системи внутрішнього контролю або витрат на організацію та проведення окремого контрольного заходу; коедіціент співвідношення витрат звітного періоду на створення/удосконалення та фрункціонування системи внутрішнього контролю у складі адміністративних витрат або витрат звітного періоду на організацію та проведення окремого контрольного заходу до одержаного чистого прибутку протягом звітного періоду; коефіціент оперативності проведення контрольних заходів; коефіцієнт своєчасності завершення контрольних заходів; коефіціент плановості проведення контр- ольних заходів; коефіцієнт виконання планів та програм контрольних заходів; коедіціент впровадження пропозицій, сформованих за наслідками контрольних заходів; коефіціент відшкодування встановленої матеріальної шкоди протягом періоду, що досліджується [17]. Наведений перелік коедріщіентів ощінки внутрішнього контролю на кожному підприемстві може уточнюватись та доповнюватись залежно від потреб.

Послідовність і набір процедур оцінювання системи внутрішнього контролю під час аудиту фінансової звітності є предметом професійного судження аудитора, і залежить від обраного ним підходу до оцінювання, методів та прийомів оцінювання.

Мета статті. Метою написання статті $є$ дослідження проблем оцінювання системи внутрішнього контролю під час аудиту фрінансової звітності підприемства, і формування способів усунення цих проблем.

Виклад основного матеріалу дослідження. 3 метою сприяння едективному збалансованому розвитку підприємства, необхідно здійснювати попередній, поточний та перспективний внутрішній контроль такого оптимального переліку об'єктів:

I. Господарські операції, зокрема в розрізі видів діяльності; витрати, доходи та фінансові результати; необоротні та оборотні активи, в т. ч. грошові потоки; зобов'язання та елементи власного капіталу; організація і ведення бухгалтерського, управлінського та інших видів обліку на підприемстві; складання і подання фрінансової, податкової та інших видів звітності тощо.

II. Miсiя, цілі, завдання в поєднанні з стратегією, тактикою, політиками в різних сферах діяльності підприемства (аспект контролю як на етапі їх формування, так і під час реалізації).

III. Ризики діяльності підприемства (в т. ч. ризики шахрайства, різні загрози зовнішнього середовища) та інші об'єкти, виходячи із специфіки підприємства і його видів діяльності. 
Вважаємо за доцільне виділяти такі елементи системи внутрішнього контролю (СВК) підприемства: організаційна модель СВК; людські ресурси, задіяні в СВК; інформаційне, технікотехнологічне та фінансове забезпечення СВК; середовище фрункціонування СВК; заходи внутрішнього контролю в рамках СВК.

Оцінювання системи внутрішнього контролю підприемства доцільно здійснювати в розрізі таких етапів:

1. Дослідження різних особливостей формування i фонкціонування СВК на конкретному підприемстві у періоді, що перевіряеться, і зокрема аналіз впливу чинників зовнішнього середовища на неї.

2. Дослідження 3 допомогою різних інструментів кожного елемента СВК.

3. Здійснення комплексного оцінювання СВК як цілісної системи в контексті взаємодії усіх їі елементів та з врахуванням впливу зовнішнього середовища.

4. Формування висновку (звіту) про стан СВК i рекомендацій щодо підвищення іiі надійності та едективності.

Оцінювання внутрішнього контролю залежить від обрання відповідних критеріїв. Разом 3 тим, серед науковців єдиного підходу до обрання таких критеріїв не напрацьовано, адже в основу оцінки вони вкладають різні критерії. Запропоновані нами критерії оцінювання системи внутрішнього контролю підприемства під час аудиту фінансової звітності наведені в табл. 1.

Чим більша відповідність СВК вищенаведеним критеріям в розрізі параметрів, тим вища надійність ціеї системи, і тим менший ризик контролю (складової аудиторського ризику) під час аудиту фінансової звітності підприемства.

Важливо зазначити, що оцінювання системи внутрішнього контролю підприемства має виконуватися одночасно 3 оцінкою його системи бухгалтерського обліку та звітності, оскільки ці системи є взаємозалежними. Розуміння системи бухгалтерського обліку аудитор одержує як на етапі попереднього її загального оцінювання під час визначення рівня аудиторського ризику, так і під час підтвердження попередньої оцінки при здійсненні деталізованих тестів контролю в розрізі ділянок обліку (об’єктів тощо) та виконанні аудиторських процедур по суті.

Маючи оцінку систем бухгалтерського обліку i внутрішнього контролю в комплексі з іншою інфрормацією про внутрішне і зовнішне середовище підприемства, його ризики, аудитор отримує такі можливості: з'ясувати для себе види потенційних суттевих перекручень, які можуть бути у фінансовій звітності; визначити фрактори, що впливають на ризик наявності суттевих помилок і порушень; запланувати достатню кількість необхідних аудиторських процедур.

Характер, час здійснення та обсяг процедур, які аудитор виконуе 3 метою ощінки системи внутрішнього контролю залежать від багатьох чинників, зокрема: організаційної структури підприемства, масштабу та особливостей його діяльності, територіального розташування підрозділів підприемства; ефрективності його комп'ютерної системи; застосовуваних заходів та інструментів внутрішнього контролю; грун- товності документального оформлення заходів контролю; рівня властивого ризику [20].

Чітке розуміння аудитором системи внутрішнього контролю підприемства, яке $€$ важливим для якості аудиторської перевірки, здобувається на основі попереднього досвіду роботи аудитора й доповнюеться: запитами до представників вищого управлінського персоналу; вивченням документів і записів, створених у рамках системи внутрішнього контролю; спостереженням за діяльністю підрозділів підприемства; аналізом здійснення комп'ютерної обробки документів тощо.

На середовище контролю суттєвий вплив має ставлення осіб, наділених найвищими управлінськими повноваженнями, до безумовного дотримання етичних принципів, а також усвідомлення цими особами своєї відповідальності за розвиток як підприемства загалом, так і системи внутрішнього контролю зокрема. Відносно середовища контролю в МСА наголошується зокрема на двох аспектах: чи підтримуеться на підприємстві культура чесності й етичної поведінки персоналу та керівного складу; чи створюють у сукупності елементи середовища контролю прийнятну основу для інших компонентів внутрішнього контролю [14]. Крім етичних моментів важливо, з'ясувати рівень компетентності персоналу. В літературних джерелах зазначено про важливість довіри до персоналу, що має грунтуватись на його професійності. Якщо персонал не відповідатиме необхідному професійному рівню, то вся система внутрішнього контролю може бути неефективною, навіть якщо інші елементи системи будуть правильно організовані. Права й обов'язки кожного співробітника повинні бути чітко сорормульовані в посадових інструкціях. Поділ відповідних обов'язків є необхідним для запобігання зловживанням (зокрема розкраданням активів), а також для виявлення випадкових помилок. Практика свідчить, що якщо один й той самий пращівник здійснюе господарську операцію й відображає ї̈ в обліку або виконує всі облікові фрункції, починаючи від складання первинних документів і закінчуючи складанням балансу, зростає ймовірність того, що багато помилок не буде виявлено або ж вони свідомо будуть приховані. Така ситуація $є$ характерною здебільшого для малих підприемств.

Також аудитор повинен розуміти, які бізнесризики є характерними для підприемства, їх суттєвість та ймовірність їх виникнення.

Від заходів внутрішнього контролю суттево залежить достовірність звітних даних, і тому зовнішній аудитор має отримати розуміння таких заходів на підприемстві, зокрема, щодо інвентаризації активів та зобов'язань, звірки взаєморозрахунків 3 контрагентами тощо. В процесі отримання розуміння процедур контролю, незалежний аудитор у першу чергу розглядає, чи фрактично здійснюються процедури контролю і яким чином (окрема конкретна процедура контролю або у поєднанні 3 іншими процедурами), чи запобігають вони або забезпечують виявлення і виправлення суттевих викривлень в класах операцій, в залишках за рахунками або в розкритті інфрормації [5]. Процедури контролю досить різноманітні і визначаються специфрікою діяльності підприемства. Важливим для системи внутрішнього контролю $є$ фрункціонування 
Критерії оцінювання системи внутрішнього контролю підприемства

\begin{tabular}{|c|c|}
\hline Критерії & Параметри оцінювання в розрізі відповідних критеріїв \\
\hline $\begin{array}{l}\text { Рівень організації } \\
\text { СВК }\end{array}$ & $\begin{array}{l}\text { - відповідність СВК вимогам законодавчо-нормативних актів до неї, враховуючи } \\
\text { організаційно-правову фрорму підприємства, його види діяльності, приналежність до } \\
\text { підприємств, що становлять суспільний інтерес тощо; } \\
\text { - відповідність СВК організаційній структурі підприємства та особливостям його діяльності } \\
\text { (масштаби діяльності; кількість видів діяльності, їх специфіка; галузь та типи ринку; } \\
\text { кількість працівників; наявність відокремлених підрозділів; входження в групу вітчизняних } \\
\text { підприємств чи в структуру міжнародної корпоращії та інше) тощо; } \\
\text { - відповідність СВК підприємства загальним принщипам формування таких систем (зокрема } \\
\text { принщипам незалежності, комплексності, інтегрованості, адаптивності та іншим [7]), а також } \\
\text { відповідність іншим вимогам до побудови СВК, регламентованих внутрішніми документами } \\
\text { підприємства (зокрема щодо підпадання під моніторинг з боку відповідного управлінського } \\
\text { персоналу чи засновників, заборони певного поєднання посад чи обов’язків, забезпечення } \\
\text { виконання конкретного спектру завдань, що поставлені перед СВК підприємства тощо); } \\
\text { - наявність: затвердженої політики підприємства щодо системи внутрішнього контролю; } \\
\text { продуманого затвердженого механізму здійснення внутрішнього контролю на підприємстві; } \\
\text { обгрунтованого плану заходів внутрішнього контролю; обгрунтованих методик здійснення } \\
\text { внутрішнього контролю різних обєктів та виявлення різних шахрайських схем тощо; } \\
\text {-орієнтованість СВК на вдосконалення обєктів контролю (враховуючи стратегію розвитку } \\
\text { підприємства тощо) та на сприяння досягненню цілей підприємства тощо. }\end{array}$ \\
\hline $\begin{array}{l}\text { Рівень людських } \\
\text { ресурсів, задіяних } \\
\text { в СВК }\end{array}$ & $\begin{array}{l}\text { - достатність професійної компетентності (знань, вмінь) працівників СВК; } \\
\text { - постійність підвищення кваліфікащї працівників СВК; } \\
\text { - наявність успішного професійного досвіду в працівників СВК; } \\
\text { - достатність кількості працівників СВК для виконання поставлених перед нею завдань, } \\
\text { враховуючи масштаб діяльності підприємства, їі специфіку тощо; } \\
\text { - універсальність працівників СВК щодо можливості здійснювати всі види заходів } \\
\text { внутрішнього контролю, будучи в разі потреби взаємозамінними та для забезпечення } \\
\text { періодичної ротації. }\end{array}$ \\
\hline $\begin{array}{l}\text { Рівень } \\
\text { інфрормаційного, } \\
\text { техніко- } \\
\text { технологічного } \\
\text { та фрінансового } \\
\text { забезпечення СВК }\end{array}$ & $\begin{array}{l}\text { - забезпеченість СВК необхідними техніко-технологічними інструментами контролю, зокрема } \\
\text { сучасними спеціалізованими технічними засобами, що використовуються для виконання } \\
\text { функцій контролю залежно від виду діяльності (сканерами, системами відеоспостереження, } \\
\text { цивільними дронами, лабораторним обладнанням, виходячи з специфіки діяльності та } \\
\text { іншим), надійною комп'ютерною технікою, службовими транспортними засобами тощо; } \\
\text { - забезпеченість СВК необхдними інформаційними системами, зокрема спеціалізованими } \\
\text { комп'ютерними програмами контролю, програмами для обробки великих обсягів індормації } \\
\text { та їі аналізу, програмними засобами встановлення регламентованого доступу до певних видів } \\
\text { інформащії для різних типів користувачів, їі захищеного зберігання і виявлення випадків } \\
\text { несанкціонованих доступів чи навмисного викривлення даних тощо; } \\
\text { - забезпеченість СВК необхідними фрінансовими ресурсами для встановлення високих } \\
\text { заробітних плат їі субєєтам і закупівлі усього необхідного як для їх повсякденної роботи, так і } \\
\text { для здійснення періодичних додаткових заходів контролю; } \\
\text { - наявність чітких обгрунтованих алгоритмів оцінки достовірності інформації на різних } \\
\text { етапах - від виникнення до використання; } \\
\text { - наявність власних великих та зручних у користуванні інформаційних баз даних щодо } \\
\text { різних напрямів внутрішнього контролю і об'єктів, що підлягають внутрішньому контролю, } \\
\text { а також доступів до необхідних зовнішніх інформаційних баз (для перевірки контрагентів, } \\
\text { юридичних та законодавчих баз тощо) }\end{array}$ \\
\hline $\begin{array}{l}\text { Стан середовища } \\
\text { фрункціонування } \\
\text { СВК }\end{array}$ & $\begin{array}{l}\text { - надійність системи бухгалтерського обліку підприемства (в тому числі підсистеми } \\
\text { оперативного обліку (складського обліку, обліку відпрацьованого робочого часу тощо); } \\
\text { - оптимальність організації і здійснення техніко-технологічних процесів та бізнес-процесів на } \\
\text { підприємстві; } \\
\text { - відсутність значних ризиків зовнішнього середовища підприємства (в т.ч. відсутність } \\
\text { суттєвих загроз на рівні галузі, ринків збуту, взаємовідносин з контрагентами (з } \\
\text { використанням різних фрорм розрахунків) тощо, а також відсутність значних загроз на } \\
\text { макрорівні і глобальному рівні); } \\
\text { - відсутність умов, можливостей та мотивів для зловживань працівниками на підприємстві } \\
\text { (зокрема в контексті відсутності на підприємстві таких аспектів: умов для розкрадань; } \\
\text { значних конфліктів чи непорозумінь в колективі чи з власниками; проявів непрофесійної } \\
\text { поведінки працівників; толерування з боку керівництва і власників будь-яких проявів } \\
\text { недоброчесності, халатності; слабких сторін підприемства, що можуть призвести до створення } \\
\text { шахрайських схем з боку працівників чи керівництва, або ж до диверсії на замовлення } \\
\text { конкурентів чи з боку рейдерів тощо); } \\
\text { - постійність ретельного моніторингу всіх елементів СВК з боку вищого керівництва (в } \\
\text { поєднанні з адекватністю та ефективністю управління) чи з боку засновників. }\end{array}$ \\
\hline $\begin{array}{l}\text { Рівень якості } \\
\text { здійснення заходів } \\
\text { внутрішнього } \\
\text { контролю в рамках } \\
\text { СВК }\end{array}$ & $\begin{array}{l}\text { - наявність професійної належної ретельності у працівників СВК під час здійснення заходів } \\
\text { внутрішнього контролю; } \\
\text { - постійність і своєчасність здійснення заходів внутрішнього контролю, в т.ч. превентивного } \\
\text { характеру та із збереженням пріоритетності контролю «критичних точок та ділянок»; } \\
\text { - відсутність невиявлених вчасно помилок, порушень (недотримання законодавства, } \\
\text { розкрадання, псування запасів через халатність працівників тощо), обману, шахрайств (в } \\
\text { т. ч. тих, що були виявлені в наступних звітних періодах під час перевірок контролюючими } \\
\text { органами, аудиторськими фірмами тощо). } \\
\text { - достатність і всеохопність (щодо всіх обєктів внутрішнього контролю) системних і } \\
\text { комплексних заходів внутрішнього контролю (в т.ч. заходів щодо виявлення ризиків у } \\
\text { внутрішньому і зовнішньому середовищі підприємства) з використанням різних методів, } \\
\text { підходів, інструментів; } \\
\text { - оптимальність витрат ресурсів на здійснення заходів внутрішнього контролю, враховуючи } \\
\text { очікувані результати від іх здійснення в поточному, тактичному і стратегічному аспектах. }\end{array}$ \\
\hline
\end{tabular}


служби внутрішнього аудиту на підприємстві. Відповідно до МСА 315 така служба є суттевим чинником якості контрольних фоннцій, здійснюваних підприємством, спираючись на внутрішні ресурси [14]. Аудиторові рекомендуеться ознайомитися 3 положенням про службу внутрішнього аудиту (контролю, моніторингу) і фрактично виконуваними фрункціями такого підрозділу зокрема шляхом аналізу звітів підрозділу про виконану роботу.

Результати ощінювання системи внутрішнього контролю будуть корисними як під час аудиту фрінансової звітності аудиторськими фрірмами, так і під час прийняття поточних, тактичних і стратегічних управлінських рішень керівництвом підприемства. Зокрема можна виділити такі напрями використання цих результатів: під час визначення аудиторського ризику в процесі планування аудиту фрінансової звітності конкретного підприемства; при визначенні обсягу вибірки і кількості необхідних аудиторських процедур, зважаючи на рівень ризику контролю; при визначенні достатності i прийнятності аудиторських доказів тощо. Для власників і вищого управлінського персоналу результати оцінювання системи внутрішнього контролю будуть корисними 3 позиції розуміння: наявного рівня запобігання помилкам і порушенням на підприемстві; величини ймовірності існування на підприемстві схем розкрадання ТМЦ та інших активів, шахрайства та інших зловживань; повноти переліку проблемних об'єктів контролю (певних ділянок обліку, конкретних бізнес-процесів, взаємовідносин з окремими контрагентами тощо) де необхідні швидкі правильні дії щодо виправлення ситуації в контексті розвитку бізнесу або з метою виправлення недоліків перед очікуваною перевіркою контролюючих органів; рівня достовірності інформації про види і масштаби резервів підприємства для підвищення рентабельності, продук- тивності, фондовіддачі; можливостей вчасного виявлення всього спектру ризиків, що загрожують підприемству в розрізі внутрішнього і зовнішнього середовища тощо.

Чим нижчим буде рівень надійності і ефрективності системи внутрішнього контролю підприємства, тим менше можуть довіряти їі результатам власники і вищий управлінський персонал. Також аналогічно чим нижчим буде рівень надійності і ефективності системи внутрішнього контролю підприємства, тим менше аудиторська фрірма може на них покладатись під час аудиту, і відповідно змушена буде збільшити кількість аудиторських процедур та обсяг необхідних аудиторських доказів для формування обгрунтованої думки в аудиторському звіті.

Висновки. Отже, незалежному аудитору під час аудиту фінансової звітності потрібно достовірно оцінити надійність та ефективність системи внутрішнього контролю підприемства, оскільки це прямо вплине на кількість необхідних аудиторських процедур для отримання достатніх і прийнятних аудиторських доказів, на рівень аудиторського ризику і якість аудиторської перевірки загалом. Причому процедури оцінювання системи внутрішнього контролю під час аудиту фрінансової звітності є обов'язковими згідно МСА незалежно від особливостей підприемства-замовника.

Проведене дослідження зокрема дало змогу визначити детальний перелік науково обгрунтованих та реальних до застосування у практищі критеріїв оцінювання системи внутрішнього контролю підприемства, а також виокремити параметри оцінювання в розрізі кожного критерію. Врахування запропонованих в статті рекомендацій сприятиме підвищенню точності оцінки надійності та ефективності системи внутрішнього контролю підприемств в тому числі під час аудиту фрінансової звітності.

\section{Список літератури:}

1. Петіна Л.В., Добруля О.О. Аудиторська оцінка, тестування та документування перевірки системи внутрішнього контролю. Бізнес-навігатор. 2011. № 2. С. 67-70.

2. Патраманська Л.Ю. Удосконалення підходів до оцінки ефективності внутрішнього контролю на підприємствах електронної комерції. Ефбективна еконоліка. 2016. № 10.

3. Король В.В. Підходи щодо оцінки ефективності внутрішньогосподарського контролю в управлінні виробництвом та реалізацією цукрових буряків. Ефбективна еконоліка. 2013. № 9.

4. Максімова В.Ф., Ковальова Н.М., Шляхов С.В. Формування критеріїв якості внутрішнього контролю. Вісник соціально-еконолічних досліджень. 2012. № 4. С. 216-223.

5. Дорош Н.І. Аудит системи внутрішнього контролю підприемства. Проблели теорії та методологї бухгалтерського обліку, контролю і аналізу. 2005. № 2(5). С. 95-108.

6. Свтушевська О.А. Оцінка ефективності системи внутрішнього контролю підприемств водного транспорту. Зовнішня торгівля: еконоліка, фбінанси, право. 2015. № 3. С. 214-221.

7. Остророг Н.В., Чубай В.М. Формування та оцінювання ефективності системи внутрішнього контролю промислового підприемства. Науковий Вісник НЛТУ Украӥни. 2011. № 21.14. С. 270-275.

8. Будник Л.А., Голяш І.Д. Оцінка системи внутрішнього контролю при дослідженні стратегічних ініціатив підприемства. Інноваційна еконоліка. 2013. № 6. С. 68-71.

9. Рядська В.В. Аудит в системі економічних відносин України: сучасний стан та концепція розвитку : монографрія. Чернігів : Видавець Лозовий В.М., 2014. 472 с.

10. Болдуев М.В. Удосконалення організаційно-методичних основ оцінювання системи внутрішнього контролю підприемства в процесі проведення зовнішнього аудиту. Вісник Запорізького національного університету. 2011. № 1(9). С. 21-27.

11. Аренс Э.Л., Лоббек Дж.К. Аудит / под ред. Я.В. Соколова. Москва : Финансы и статистика, 2001. 560 с.

12. Аудит Монтгомери / Ф.Л. Дефлиз, Г.Р. Дженник, В.М. О’Рейли, М.Б. Хирш; под ред. Я.В. Соколова; пер. с англ. С.М. Бычковой. Москва : Аудит, ЮНИТИ, 1997. 542 с.

13. Петрик О.А., Савченко В.Л., Свідерський Д.Є. Організація та методика аудиту підприемницької діяльності : навч. посіб. Київ : КНЕУ, 2008. 482 с.

14. Міжнародні стандарти контролю якості, аудиту, огляду, іншого надання впевненості та супутніх послуг : Видання 2016-2017 років / пер. з англ. О.Л. Ольховікова, М.К. Шульман. Київ : АПУ, 2016. 1142 с.

15. Загородній А.Г., Корягін М.В. Аудит: теорія і практика : навч. посіб. Львів : Видавництво національного університету «Львівська політехніка», 2004. 456 с. 
16. Бондар М.І. Аудит в АПК : навч. посіб. Київ : КНЕУ, 2003. 188 с.

17. Шерстюк О.Л. Аудиторська оцінка ризику неефективності системи внутрішнього контролю. Глобальні та національні проблеми еконоліки. 2015. № 8. С. 1200-1204.

18. Сметанко О.В. Оцінка службою внутрішнього аудиту системи бухгалтерського обліку і внутрішнього контролю в акціонерних товариствах України. Вісник СумДУ. Серія “Еконоліка». 2011. № 3. С. $137-150$.

19. Бардаш С.В., Осадча Т.С. Окремі аспекти якісного і кількісного оцінювання ефекту та ефективності внутрішнього контролю. Еконоліка та держава. 2011. № 11. С. 16-19.

20. Безверхий К. Методика використання аналітичних процедур при оцінці ефективності системи внутрішньогосподарського контролю підприемства. Бухгалтерський облік і аудит. 2014. № 11. С. 17-24.

\section{References:}

1. Petina L.V., Dobrulja O.O. (2011) Audytorsjka ocinka, testuvannja ta dokumentuvannja perevirky systemy vnutrishnjogho kontrolju [Audit assessment, testing and documentation of inspections of internal control systems]. Business navigator, no. 2, pp. 67-70.

2. Patramansjka L.Ju. (2016) Udoskonalennja pidkhodiv do ocinky efektyvnosti vnutrishnjogho kontrolju na pidpryjemstvakh elektronnoji komerciji [Improving approaches to assessing the effectiveness of internal control in e-commerce enterprises]. Efficient economy, no. 10.

3. Korolj V.V. (2013) Pidkhody shhodo ocinky efektyvnosti vnutrishnjoghospodarsjkogho kontrolju v upravlinni vyrobnyctvom ta realizacijeju cukrovykh burjakiv [Approaches to assessing the effectiveness of internal control in the management of production and sale of sugar beets]. Efficient economy, no. 9.

4. Maksimova V.F., Kovaljova N.M., Shljakhov Je.V. (2012) Formuvannja kryterijiv jakosti vnutrishnjogho kontrolju [Formation of quality control criteria for internal control]. Bulletin of socio-economic research, no. 4, pp. 216-223.

5. Dorosh N.I. (2005) Audyt systemy vnutrishnjogho kontrolju pidpryjemstva [Audit of the internal control system of the enterprise]. Problems of theory and methodology of accounting, control and analysis, no. 2(5), pp. 95-108.

6. Jevtushevsjka O.A. (2015) Ocinka efektyvnosti systemy vnutrishnjogho kontrolju pidpryjemstv vodnogho transportu [Evaluation of the effectiveness of the system of internal control of water transport enterprises]. Foreign trade: economics, finance, law, no. 3, pp. 214-221.

7. Ostrorogh N.V., Chubaj V.M. (2011). Formuvannja ta ocinjuvannja efektyvnosti systemy vnutrishnjogho kontrolju promyslovogho pidpryjemstva [Formation and evaluation of the effectiveness of the internal control system of an industrial enterprise]. Scientific Bulletin of NLTU of Ukraine, no. 21.14, pp. 270-275.

8. Budnyk L.A., Gholjash I.D. (2013) Ocinka systemy vnutrishnjogho kontrolju pry doslidzhenni strateghichnykh iniciatyv pidpryjemstva [Valuation of the internal control system in the study of strategic initiatives of the enterprise]. Innovative economy, no. 6, pp. 68-71.

9. Rjadsjka V.V. (2014) Audyt v systemi ekonomichnykh vidnosyn Ukrajiny: suchasnyj stan ta koncepcija rozvytku [Audit in the system of economic relations of Ukraine: current state and concept of development]. Chernihiv: Publisher Lozovy V. M. (in Ukrainian)

10. Boldujev M.V. (2011) Udoskonalennja orghanizacijno-metodychnykh osnov ocinjuvannja systemy vnutrishnjogho kontrolju pidpryjemstva $\mathrm{v}$ procesi provedennja zovnishnjogho audytu [Improving the organizational and methodological basis for evaluating the system of internal control of the enterprise in the process of conducting an external audit]. Bulletin of Zaporizhia National University, no. 1(9), pp. 21-27.

11. Arens E.L., Lobbek Dzh.K. (2001) Audyt [Audit]. Moscow: Finance and Statistics. (in Russian)

12. Defliz F.L., Dzhennik Gh.R., O'Rejli V.M., Hirsh M.B. (1997) Audyt Montghomeri [Audit of Montgomery]. Moscow: Audit, UNITY. (in Russian)

13. Petryk O.A., Savchenko V.L., Svidersjkyj D.Je. (2008) Orghanizacija ta metodyka audytu pidpryjemnycjkoji dijaljnosti [Organization and methods of business audit]. Kyiv: KNEU (in Ukrainian)

14. Oljkhovikov O.L., Shuljman M.K. (transl.) (2016). Mizhnarodni standarty kontrolju jakosti, audytu, oghljadu, inshogho nadannja vpevnenosti ta suputnikh poslugh: Vydannja 2016-2017 rokiv [International standard quality control, audit, review, other hope for exclusivity and related services: Edition 2016-2017]. Kyiv: APU.

15. Zaghorodnij A.Gh., Korjaghin M.V. (2004) Audyt: teorija i praktyka [Audit: theory and practice]. Ljviv: Vydavnyctvo nacionaljnoho universytetu «Ljvivsjka politekhnika».

16. Bondar M.I. (2003) Audyt v APK [Audit in APC]. Kyiv: KNEU. (in Ukrainian)

17. Sherstjuk O.L. (2015). Audytorsjka ocinka ryzyku neefektyvnosti systemy vnutrishnjogho kontrolju [Audit assessment of the risk of inefficiency of the internal control system]. Global and national economic problems, no. 8, pp. 1200-1204.

18. Smetanko O.V. (2011) Ocinka sluzhboju vnutrishnjogho audytu systemy bukhghaltersjkogho obliku i vnutrishnjogho kontrolju v akcionernykh tovarystvakh Ukrajiny [Assessment by the internal audit service of the accounting and internal control system in joint-stock companies of Ukraine]. Bulletin of SSU. Economics Series, no. 3, pp. $137-150$.

19. Bardash S.V., Osadcha T.S. (2011) Okremi aspekty jakisnogho i kiljkisnogho ocinjuvannja efektu ta efektyvnosti vnutrishnjogho kontrolju [Some aspects of qualitative and quantitative assessment of the effect and effectiveness of internal control]. Economy and state, no. 11, pp. 16-19.

20. Bezverkhyj K. (2014) Metodyka vykorystannja analitychnykh procedur pry ocinci efektyvnosti systemy vnutrishnjoghospodarsjkogho kontrolju pidpryjemstva [Methodology of using analytical procedures in assessing the effectiveness of the system of internal control of the enterprise]. Accounting and auditing, no. 11, pp. 17-24. 